\title{
The Use of Medical Theses
}

As Demonstrated by Journal

Citations, $1850-1960$

\section{By L. MILES RAISIG and FREDERICK G. KILGOUR}

THE STUDY reported in this paper arose from consideration of the question whether the Yale medical library should retain in part or in whole its collection of somewhat more than one hundred thousand European medical theses published largely in the last seventy years. Experience of recent years has been that theses attract infinitesimal demand, which suggests that they may never have enjoyed significant amounts of use. The Yale medical library has responsibility for maintaining collections as source materials for historical research, but if theses had not been used in literature of the past, there would be little if any justification in preserving such large holdings. Therefore, it was to determine whether theses had been used in older literature that this investigation was undertaken. The findings are published in the belief that they will be useful to those institutions faced with making decisions on the management of theses, both old and current, and also to those contemplating collecting theses for general or historical purposes.

\section{Methods and Materials}

It was believed that an analysis of citation use would provide the most significant data on the medical thesis. Therefore, the following basic statistics were considered to be of primary importance and were sought and recorded: source and bibliographical data of the thesis citation (journal, volume, page, year; author, title, university, year of publication);
Mr. Raisig is Head, Acquisitions Section, and Mr. Kilgour is Librarian, Yale Medical Library. This investigation was pursued as part of the Selective Book Retirement Program, Yale University Library, supported by a grant from the Council on Library Resources.

number of total citations, of citations to journal articles, of thesis citations, and of all other nonjournal citations.

Medical journals were chosen as the best and most easily available sources of citations for analysis, their usefulness having been well established in many earlier citation studies. The period 1885-1960 was tentatively selected for analysis because of the year limits of the Yale medical library's thesis collection, and because it appeared to offer the most significant data on the use of the thesis.

The expected infrequency of the dissertation citation demanded inverse sampling, or complete analysis, of all references appearing within the selected unit of issue of any source journal. This full analysis, together with the necessity to confine the study within the time allowed, limited the number of source journals to ten. A staggered, random pattern of source publication analysis was devised, each journal being studied in its every tenth year, so that with the exception of 1946, complete coverage was secured from 1898 through 1961 without duplication.

To assure objectivity as well as sig- 
TABLE 1. Citation Source Journals

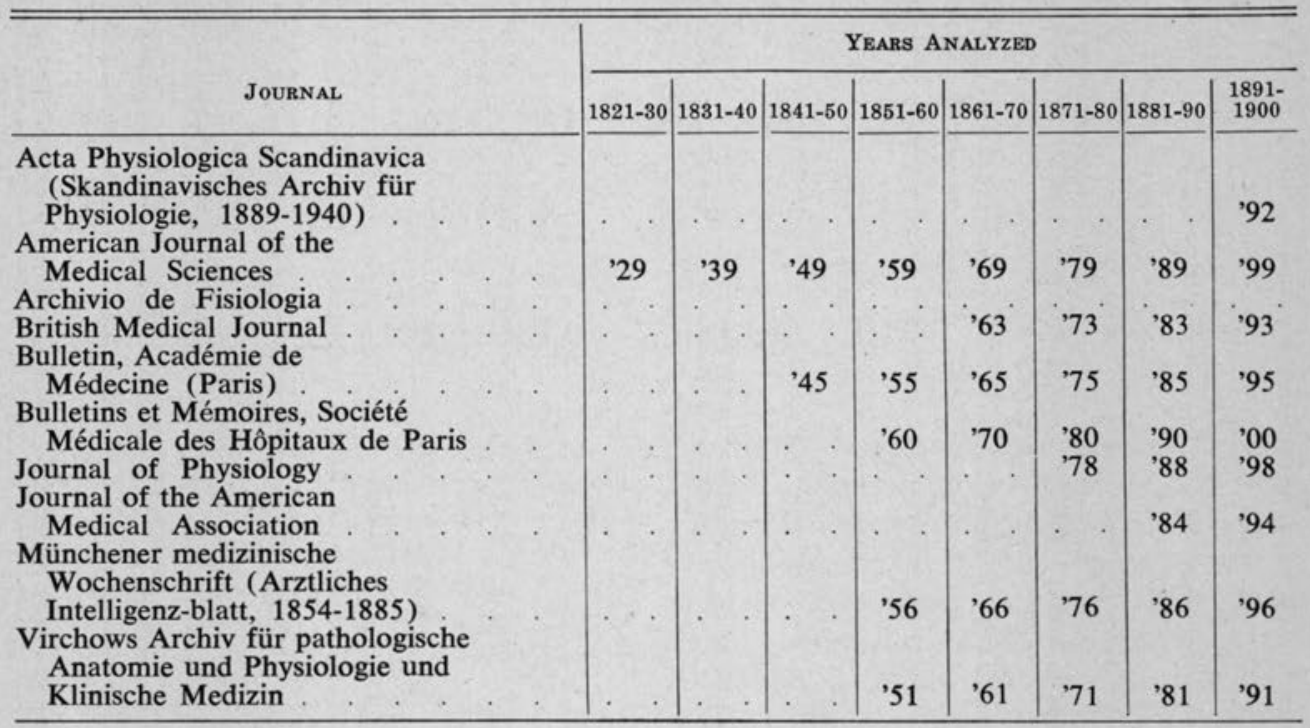

nificance in the choice of the citation population for study, nine of the ten source journals were selected from Ash, Serial Publications Containing Medical Classics: An Index to Citations in Garrison-Morton, ${ }^{1}$ on showing there relatively high individual indexes of classic worth. The index for each of the nine journals was found by dividing the number of classic articles by the number of inclusive years of publication as given in Ash's compilation. Other criteria for selecting the source journals were variety of geographical origin, variety of frequency of publication, variety of articles on theoretical, experimental, and clinical medicine, and number of years of publication.

The tenth source journal, Archivio di Fisiologia, was chosen largely for its availability and the need for a source in Italian. The presence in the study of four journals concerned with physiology is coincidental and unplanned. Table 1 contains a list of the titles and years of all journals analyzed, representing 195 volumes and part volumes.

\footnotetext{
1 Lee Ash, Serial Publications Containing Medical Classics: An Index to Citations in Garrison-Morton (New Haven: The Antiquarium, 1961).
}

The primary sources of citations in the investigation were original articles, as well as addresses, reports, case records and letters in the form and with the substance of original articles, correspondence relating to articles, and nonabstracted and unabridged proceedings. The following were excluded from analysis: abstracts of articles and proceedings; editorials; book lists, reviews, and bibliographical notices; reports of societies; obituaries, necrology lists, biographical notices, and appreciations; news items; legal notices; public health statistics; question and answer columns; dissertation lists; unsigned and noncredited materials. No attempt has been made to secure for analysis those few bibliographies omitted by the publisher for lack of space from later volumes of Münchener Medizinische Wochenschrift and Journal of the American Medical Association.

The following definitions and methods have been used throughout the study. Any cited work known to have been published fewer than four times a year has been treated as a nonjournal. If the frequency of a cited work could not be de- 


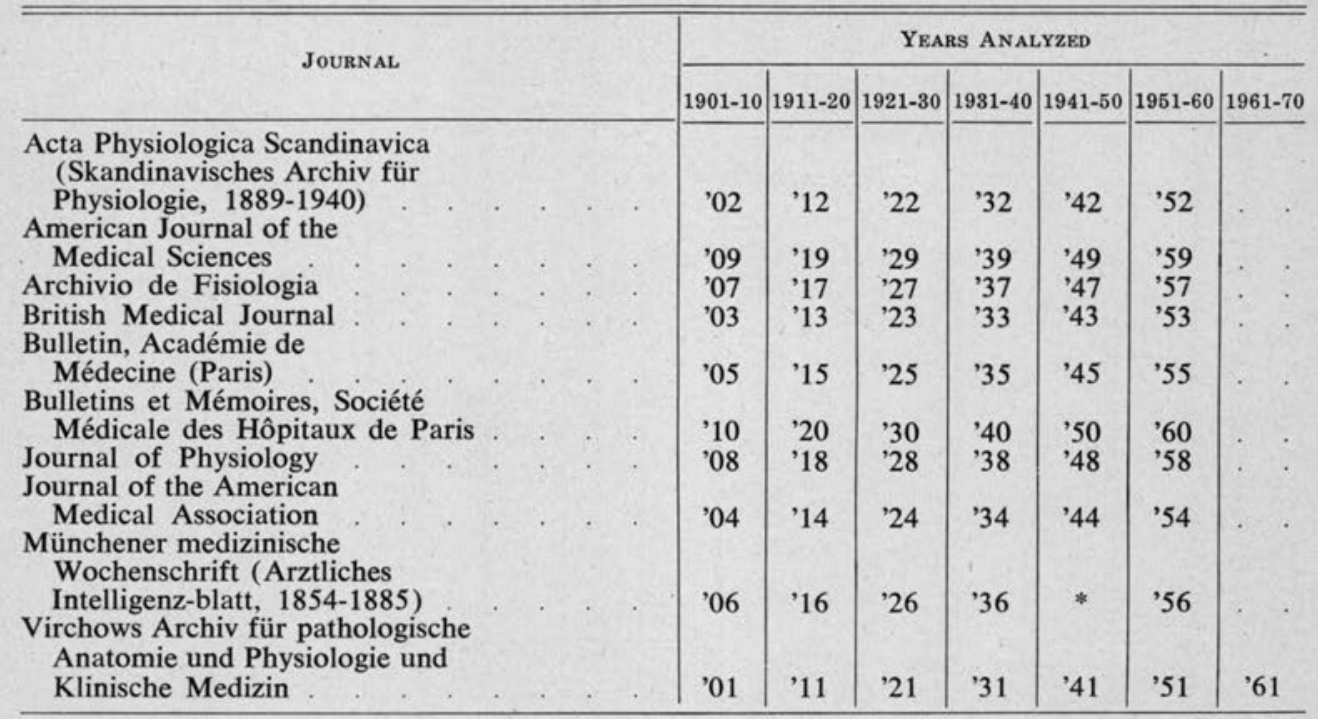

* Not published 1946.

termined easily without searching, the citation was included in the total count as a journal. Replicate citations occurring within the same source article, and referring to a single work by the same author, have not been counted. This rule includes citations to theses. Each replicate citation to the same thesis, occurring in different source articles, has been recorded. Every effort has been made to identify by university and year imperfect dissertation references, of which only ten remained incomplete. ${ }^{2} \mathrm{~A}$ citation to an unidentified author, the title of whose work has been

\footnotetext{
${ }^{2}$ France, Ministère de l'Education Nationale. Catalogue des Thèses et Ecrits Académiques . . 1884/85(Paris : 1885-).

Jahresverzeichnis der deutschen Hochschulschriften, Bd. I- , 1885. (Berlin und Leipzig: Börsenverein der deutschen Buchhändler, 1887-).

U, S, Armed Forces Medical Library, Index-Catalogue of the Library of the Surgeon-General's Office, United States Army (Washington: Government Printing Office, 1880-95 ; 2d ser., 1896-1916; 3d ser., 191832 ; 4 th ser., $1936-55$ ).

U. S. National Library of Medicine. Index-Catalogue of the Library of the Surgeon-General's Office, National Library of Medicine. 5th ser. (Washington: Government Printing Office, 1959-61).

World Health Organization. World Directory of Medical Schools, 2d ed. (Geneva, 1957).

Yale Medical Library. Card Catalog of Medical Theses.
}

omitted, has been included in the count of journal references.

Dissertations accepted and recorded were: thèse; akademisk afhandling; proefschrift; Inauguraldissertation; Inauguralabhandlung; Doktorarbeit; Dissertationsarbeit; Akademische Abhandlung; and the equivalents "D.J.", "I.D.", “J.D."” The following monographs were excluded as theses, but were included in the nonjournal count: Habilitationsschrift; Fakultatsrede; Gratulationsschrift; concours; thèse de concours; thèse d'agrégé; thèse d'agrégation; medical nondoctoral theses; nonmedical doctoral theses. ${ }^{4}$ Dissertations published as journal articles were counted as such; a separate recording was kept of these and of four of the classes above, and will be discussed in the results section.

The citation recording technique involved a continuing threefold operation: the counting of every citation on a mechanical hand counter; the tallying of every citation to a nonjournal work (ex-

\footnotetext{
${ }^{3}$ [Medical Qualifications]. London Medical Record, $\mathrm{X}$ (September 15, 1882), 345-86; London Medical Record, N.S. II (September 20, 1889), 349-95.

Ibid.
} 


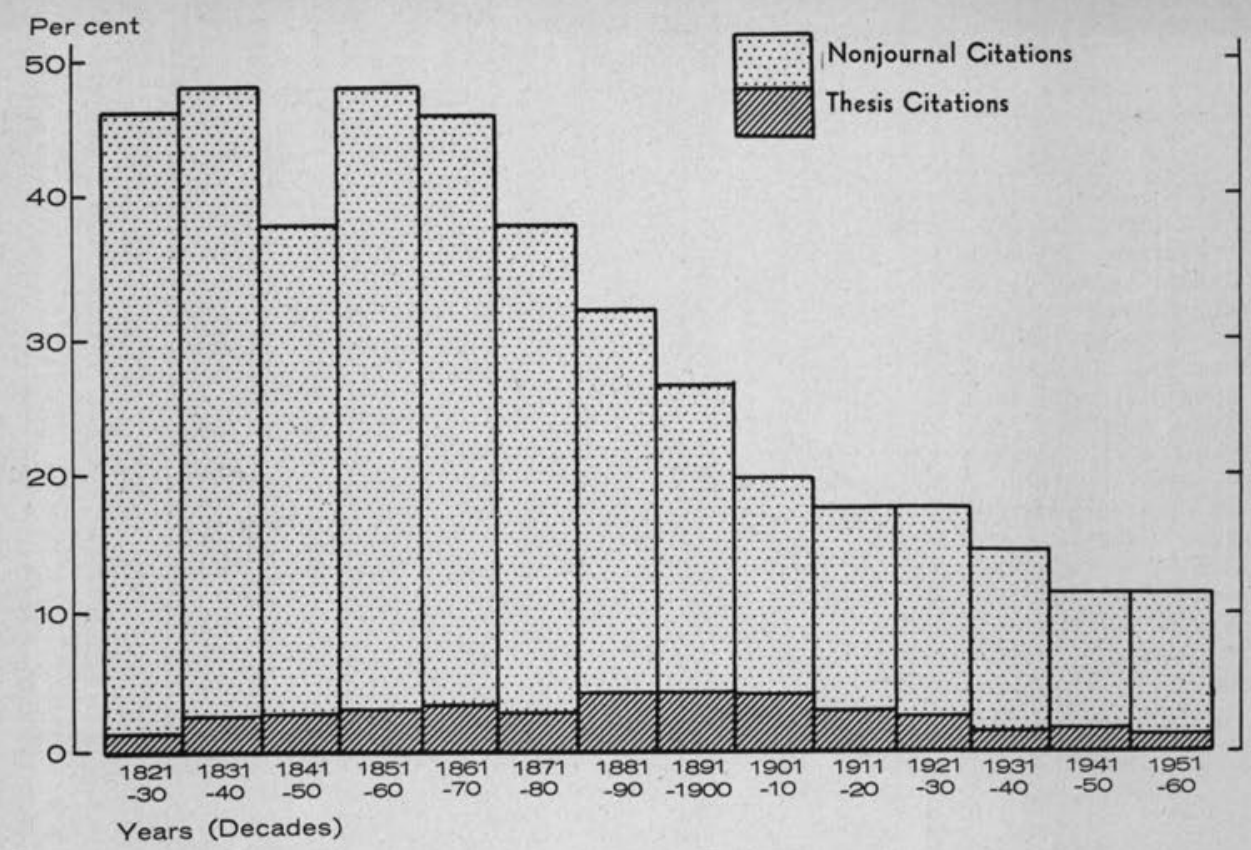

Figure 1. Distribution OF THESIS AND OTHER NONJOURNAL CITATIONS AS PERCENTAGES OF TOTAL CITATIONS.

cluding the thesis) on a special work sheet; and the separate recording of every thesis reference on a $3 \times 5$-inch slip individually numbered by source journal.

Citation counts were assembled in tables by journals and source years. At the completion of the analysis of each journal the percentage relationship of thesis citations to all citations was plotted on a

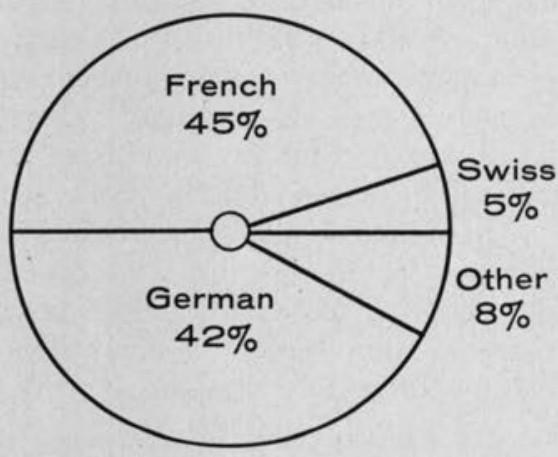

Figure 2. NATIONAL DISTRIBUtion OF THESES CITED. master line graph. This enabled ready contrast of the journal yield of citations and led to the extension of the analysis back to the middle of the nineteenth century.

\section{Results}

A total of 2,669 citations to 2,452 individual dissertations published as separate monographs turned up in the analysis of 140,534 references. Of the 2,669 citations, ten are incomplete and unidentified as to place or year; except in Figure 1, these ten have been excluded from all calculations and illustrations. Figure 1 provides the distribution by decades of thesis and other nonjournal citations as percentages of total citations, and the relationship of nonjournal to journal citations, for the period 1821-1960. There is seen here a steady growth in the citing of theses from the 0.8 per cent of 182130 to the high points of 4 and 3.9 per cents in 1881-1910, with a slight fall dur- 
TABLE 2.

Distribution OF THESES BY UNIVERSITY

\begin{tabular}{|c|c|c|c|c|c|c|c|c|c|}
\hline Rank & University & Theses & $\begin{array}{l}\text { Replicate } \\
\text { Citations } \\
\end{array}$ & $\begin{array}{c}\text { Total } \\
\text { Citations }\end{array}$ & Rank & University & Theses & $\begin{array}{l}\text { Replicate } \\
\text { Citations }\end{array}$ & $\begin{array}{c}\text { Total } \\
\text { Citations }\end{array}$ \\
\hline 1 & Paris . . . & 880 & 83 & 963 & . & Helsinki . & 5 & 0 & 5 \\
\hline 2 & Berlin . . & 136 & 18 & 154 & & Marseilles. & 5 & 0 & 5 \\
\hline 3 & München . & 91 & 6 & 97 & & Moscow & 5 & 0 & 5 \\
\hline 4 & Lyons & 84 & 5 & 89 & 51 & Glasgow : & 4 & 0 & 4 \\
\hline 5 & Würzburg. & 75 & 6 & 81 & & Lausanne : & 4 & 0 & 4 \\
\hline 6 & Dorpat . & 68 & 15 & 83 & & Uppsala . & 4 & 1 & 5 \\
\hline 7 & Zürich : & 65 & 3 & 68 & 54.5 & Groningen . . & 3 & 1 & 4 \\
\hline 8 & Leipzig . & 59 & 4 & 63 & & Mainz . & 3 & 0 & 3 \\
\hline 9 & Bonn . & 53 & 2 & 55 & & Münster : & 3 & 0 & 3 \\
\hline \multirow{2}{*}{10.5} & Halle . . & 47 & 0 & 47 & & Pennsylvania . & 3 & 0 & 3 \\
\hline & St. Petersburg & 47 & 1 & 48 & 57.5 & Erfurt & 2 & 0 & 2 \\
\hline 12 & Marburg & 46 & 6 & 52 & & Kazan & 2 & 0 & 2 \\
\hline 13 & Giessen. & 44 & 2 & 46 & 75 & Athens . & 1 & 0 & 1 \\
\hline \multirow{2}{*}{14.5} & Kiel . & 43 & 1 & 44 & & Bahia & 1 & 0 & 1 \\
\hline & Königsberg & 43 & 3 & 46 & & Bamberg . & 1 & 0 & 1 \\
\hline 16 & Breslau. & 41 & 2 & 43 & & Birmingham & 1 & 0 & 1 \\
\hline 17 & Strasbourg & 40 & $\overline{7}$ & 47 & & Boston . & 1 & 0 & $\hat{1}$ \\
\hline \multirow[t]{2}{*}{18.5} & Freiburg . & 39 & 1 & 40 & & Brussels. & 1 & 0 & 1 \\
\hline & Göttingen & 39 & 5 & 44 & & Budapest : & 1 & 0 & 1 \\
\hline \multirow[t]{2}{*}{20.5} & Greifswald & 37 & 6 & 43 & & Cape Town & 1 & 0 & 1 \\
\hline & Tübingen . & 37 & 3 & 40 & & Columbia. & 1 & 0 & 1 \\
\hline 22 & Erlangen & 33 & 4 & 37 & & Danzig : & 1 & 0 & 1 \\
\hline 23 & Heidelberg & 31 & 1 & 32 & & Düsseldorf & 1 & 0 & $\hat{1}$ \\
\hline 24 & Bordeaux. & 28 & 0 & 28 & & Durham & 1 & 0 & $\hat{1}$ \\
\hline 25 & Jena ... & 26 & 1 & 27 & & Florence & 1 & 0 & 1 \\
\hline 26 & Geneva . & 25 & 2 & 27 & & Ghent . & 1 & 0 & 1 \\
\hline 27 & Montpellier & 22 & 0 & 22 & & Harderwijk & 1 & 0 & 1 \\
\hline \multirow[t]{2}{*}{28.5} & Copenhagen & 21 & 3 & 24 & & Jassy . . & 1 & 0 & 1 \\
\hline & Rostock & 21 & 4 & 25 & & Kharkov & 1 & 0 & 1 \\
\hline 30 & Bern . & 16 & 1 & 17 & & Kiev . . & 1 & 0 & 1 \\
\hline \multirow{3}{*}{32.5} & Basel. & 15 & 2 & 17 & & Lima . . & 1 & 0 & 1 \\
\hline & Lille: & 14 & 0 & 14 & & Lisbon . . & 1 & 0 & 1 \\
\hline & Nancy & 14 & 0 & 14 & & London . . & 1 & 0 & 1 \\
\hline \multirow[t]{2}{*}{34.5} & Algiers : & 11 & 1 & 12 & & North Carolina & 1 & 0 & 1 \\
\hline & Toulouse & 11 & 0 & 11 & & Odessa & 1 & 0 & 1 \\
\hline \multirow[t]{2}{*}{36.5} & Frankfurt & 9 & 1 & 10 & & São Paulo . & 1 & 0 & 1 \\
\hline & Leyden & 9 & 1 & 10 & & Stettin & 1 & 0 & 1 \\
\hline \multirow{4}{*}{$\begin{array}{l}38 \\
40\end{array}$} & Edinburgh . & 8 & 1 & 9 & & Turin & 1 & 0 & 1 \\
\hline & Hamburg. & 7 & 0 & 7 & & Victoria . & 1 & 0 & 1 \\
\hline & Köln . & 7 & 0 & 7 & & Vienna & 1 & 0 & 1 \\
\hline & Stockholm & 7 & 1 & 8 & & Warsaw . & 1 & 0 & 1 \\
\hline \multirow[t]{3}{*}{43} & Bucharest & 6 & 1 & 7 & & Washington & 1 & 0 & 1 \\
\hline & Buenos Aires & 6 & 0 & 6 & & Witwatersrand & 1 & 0 & 1 \\
\hline & Utrecht . . & 6 & 0 & 6 & & Yale .... & 1 & 0 & 1 \\
\hline 47 & $\begin{array}{l}\text { Amsterdam } \\
\text { Cambridge }\end{array}$ & $\begin{array}{l}5 \\
5\end{array}$ & 1 & $\begin{array}{l}6 \\
6\end{array}$ & & $\begin{array}{l}\text { Totals } \\
\text { Total Univers }\end{array}$ & $\begin{array}{l}2,452 \\
\text { sities: } 90\end{array}$ & 207 & 2659 \\
\hline
\end{tabular}

ing 1871-80 stemming apparently from the effects of the Franco-German War of 1870-71. The marked decline in thesis citation which begins in the decade 191120 appears not to be due wholly to World War I influences, for there is no recovery in 1921-30 and 1931-40. The continued fall from 1931 to 1960 breaks with a slight rise occurring during the period of the later years of World War II then reaches a low of 0.7 per cent for the last decade.

The arithmetical mean of thesis citations, as a proportion of total citations for the analysis years $1821-1961$, is 16 per 1000 . For the years of greatest citation use, $1881-1910$, the proportion is 40 per 1000 . Of the 2,559 citations to identified 
dissertations, 207, or less than 8 per cent, are replicates.

The steady rise in the citation use of medical journal articles in the last hundred years is clearly shown in Figure 1. Citations to journal literature in the decade $1941-50$ accounted for 59.8 per cent of all citations found; from 1851-60 to 1951-60 the proportion of journal citations to all citations rose from 49.4 to 87.3 per cent in an apparently nonreversible trend. This rise should not be considered the absolute cause of the percentage loss in thesis citation use dating from 1901-10. Related measurements of use will demonstrate in the discussion following a real decline in the citing of theses, stemming probably from a variety of factors.

Table 2 offers the numerical distribution of theses cited and replicate thesis citations among all universities represented, with a ranked list of the latter. The very great number of Paris theses is balanced by the reduced total of dissertations from nine other French universities; the combined total of theses cited from all French universities is sixtyseven more than the total from all German universities. Berlin is the most cited of the twenty-eight German universities represented. Neither nation is favored in replicate citations to its theses; for each nation these amount to about 8 per cent of its total thesis citations. Because of its staff, tradition, and influence, Dorpat has been considered a German university outside of Germany, although it was Russian politically and geographically; all Dorpat theses cited were published between 1836 and 1905 , almost wholly within the period of German strength.

Figure 2 illustrates the national distribution of individual dissertations cited. Noteworthy is the fact that French, German, and Swiss theses account for 92 per cent of the total cited, as well as the extreme paucity of British, Italian, Spanish, and North and South American dissertations, greatly outnumbered in turn by Russian and Scandinavian theses. The inclusion of replicates in computing the national distribution of thesis citations favors only French theses in this proportion: French, 46 per cent; German, 42 per cent; Swiss, 5 per cent; others, 7 per cent. The disproportion of citations yielded ( 9 per cent) by the two French source journals, and of citations to French dissertations (46 per cent) is remarkable; the proportion of citations yielded by the two German source journals (32 per cent) more nearly approaches that of citations to German theses (42 per cent).

Illustrated in Figure 3 is the distribution of the dates of publication of theses from French universities. The first noticeable rise in the number of dissertations cited occurs in the period 1851-55, and this quantity remains almost the same until 1870. In the five-year period including the Franco-German War of 1870-71 there begins a series of sharp increases in the number of citations, reaching a

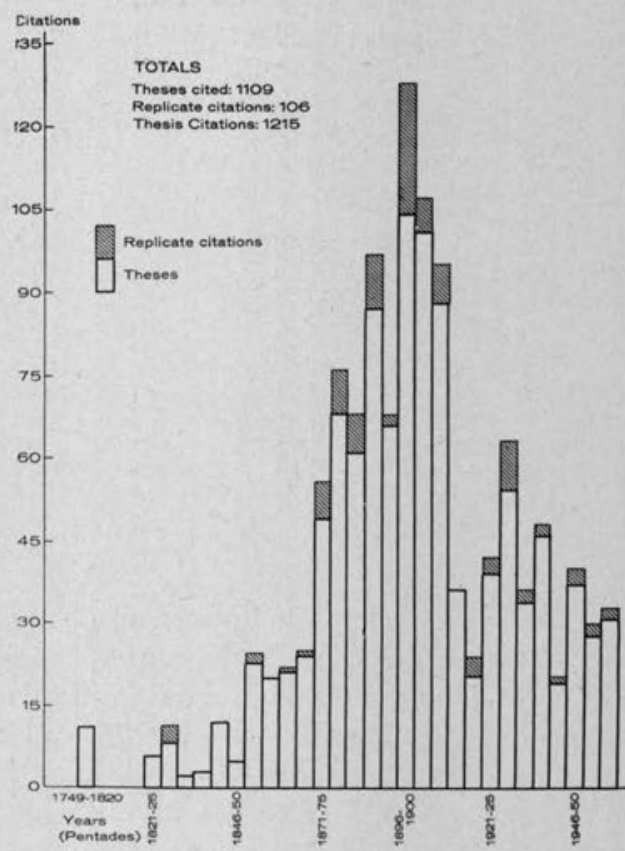

Figure 3. Distribution OF French UNIVERSITY THESES BY YEARS OF PUBLICATION, 1749-1960. 
peak in 1896-1900, falling to a low in 1916-20, and showing a fluctuating, diminishing number from 1926 to 1960 .

Figure 4 portrays the distribution of the dates of publication of cited dissertations from German universities. This is similar to the distribution of French university theses, but the first great increase in number occurs in 1846-50, five years earlier than the corresponding increase in number of French theses, and reaches its highest point in 1891-95, five years earlier than the French peak. The first marked decrease in number occurs in 1906-10, with a decline continuing to 1956-60. There are noticeably more French theses than German theses cited during the period 1921-60, and the number of French theses remains more than twice that of the German number at the end of this period.

In an attempt to secure an index of citation use based on the number of theses available for citation, those theses most cited-University of Paris-were chosen for sampling. During the calen- dar years 1891-1900 there were presented to the Paris medical faculty a total of 5,520 theses. ${ }^{5}$ Within this same period it was found that forty-nine of these had been cited. By substitution in the formula

$$
\begin{gathered}
\begin{array}{c}
\text { number of theses subsequently } \\
\text { cited }
\end{array} \\
\hline \begin{array}{c}
\text { number of theses originally } \\
\text { published }
\end{array}
\end{gathered}
$$

the index of citation use for this period was calculated to be 9 . During the calendar years 1951-60 there was presented to the Paris medical faculty a total of 11,013 theses, ${ }^{6}$ of which thirty-four were found to have been cited in the same years. By substitution in the formula above, the index of citation use for this period was found to be 3 , or one-third of the index for 1891-1900.

While these indexes offered new evidence of the decline in the citation use of the medical thesis, they could not yield any measurement of citation use beyond

\footnotetext{
s France Ministère de l'Education Nationale. Catalogue des Thèses, op. cit.

André Hahn, Personal Communication, May 24, 1962 .
}

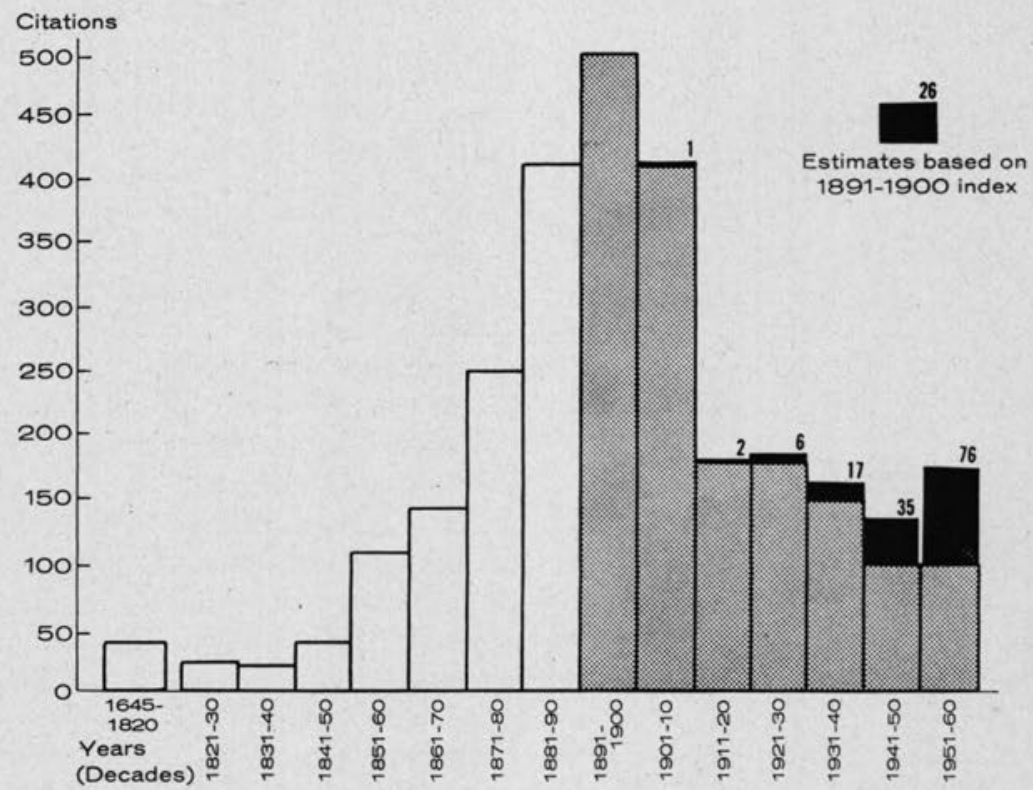

Figure 5. DisTRIBUTION OF THESIS CITATIONS BY YEARS OF THESIS PUBLICATION, 1645-1960; ADJUSTED ESTIMATES OF CITATIONS TO THESES PUBLISHED 1901-1960. 
the two decades actually investigated. The Paris theses published from 1891 to 1900 were reviewed, therefore, for citation use from 1891 to 1960 . Of these theses 136 were cited, and this number produced for the seventy-year period an index of citation use of 25 .

As a further measurement of use there was computed the citation lag of Paris dissertations published 1891-1900 and cited 1891-1960. This was based on citations to 136 individual theses and on fourteen replicate citations. It was found that 49.3 per cent of all citations occurred within the first ten years following publication, and 32.7 per cent within the second ten-year period; thus, 82 per cent of the citation use life lay within the first twenty years after publication. The remaining 18 per cent was spread from the twenty-first to the fifty-eighth postpublication year. The heaviest use occurred during the first and second years following publication, in each of which 9 per cent of the citations fell.

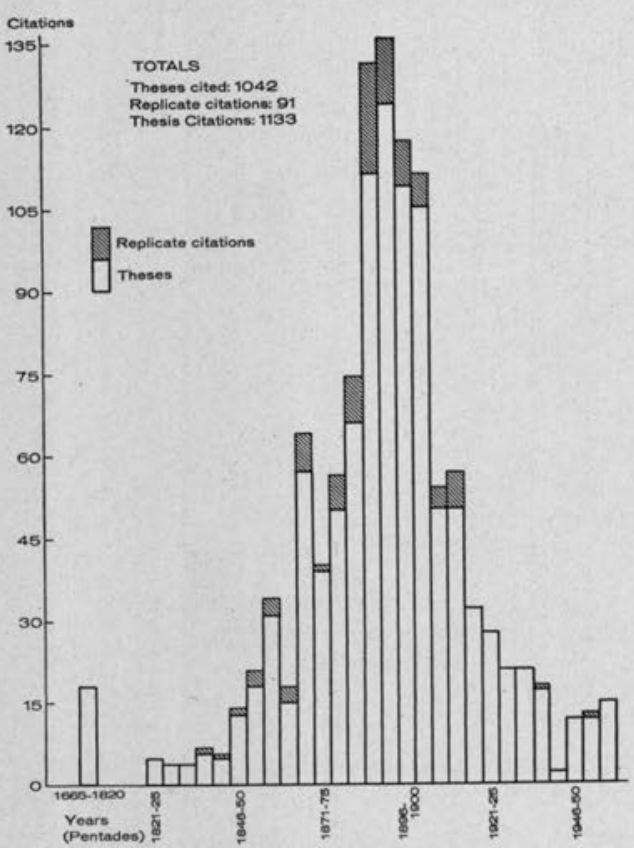

Figure 4. Distribution of German UNIVERSITY THESES BY YEARS OF PUBLICATION, 1665-1960.
There is offered in Figure 5 the distribution of thesis citations by years of thesis publication, 1645-1960. There is also shown, as the concluding step in the measurement of citation use, a series of adjusted estimates of the numbers of citations to theses published 1901-60. The number of citations to theses published $1891-1900,502$, was selected as a base from which the probable use lag in the six decades to follow 1960 might be computed. The same citations to theses published 1891-1900 were separated by decade of citation use. For the decades 18911900 through 1951-60, these citations totaled respectively $120,204,91,55,20$, 6 , and 6 .

The adjusted number of citations to theses published 1901-10 was derived from the formula

\section{citations $1951-60$ to theses published 1891-1900 \\ total thesis citations 1891-1900 $\times 100$.}

This number, 1 , was then added to the 1901-10 total of 416. The adjusted number of citations to theses published $1911-20$, 2, was secured with the formula

citations $1941-60$ to theses published 1891-1900

total thesis citations $1891-1900 \times 100$,

and was added then to the 1911-20 total, 178. In this way the citation total of each succeeding decade from 1901-10 through 1951-60 has been adjusted to give a figure to represent estimated citations on the basis of all theses having been available for citation throughout equal periods of time.

The chart clearly demonstrates the continued fall, even after adjustment, in the number of citations to dissertations published since 1900 . The decline breaks in 1951-60, and there is insufficient evidence to determine if the 1951-60 total represents an actual leveling-off or merely a temporary cessation in the decline.

Although this study has been con- 
cerned primarily with the dissertation prepared for the doctorate in medicine and published and distributed as a separate monograph, other medical and nonmedical theses have been found and recorded separately: sixteen medical nondoctoral theses, including those granted by the University of Minnesota for study at the Mayo Clinic; twenty-five theses submitted for doctor of philosophy degrees in the nonmedical sciences; twentynine thèses de concours (competition essays) and Habilitationsschriften (introduction-to-teaching essays); forty-seven medical doctoral theses published as articles in the various Scandinavian Acta and their supplements, and two similar theses published in other journals. These total 119 , and with twelve replicate citations account for less than 0.1 per cent of all citations analyzed.

We may dismiss without further consideration these extra theses, with the exception of those appearing as articles in journals and other serials. This type of publication in recent Scandinavian Acta is the later expression of a phenomenon associated with German medical theses since before 1895 . Such publication of the latter is of particular interest, since there is reason to believe that it has been and continues to be a factor in the decline of the citation use of German theses in their separate monographic form.

In a full count of the German university medical theses listed in Jahresverzeichnis der deutschen Hochschulschriften every fifth year from 1895-96 through $1936,{ }^{7}$ it was found that the number published as serial articles rose in an almost unbroken sweep from fifty-two to 547 . The proportion of theses published as serial articles rose from 4.4 per cent in $1895-96$ to 18.4 per cent in 1916 , dropped to 3.7 per cent in 1921 , then rose to 14 per cent to 1931 , and declined to 11.7 per cent in 1936. It is remarkable to find that these two periods of increasing serial publication occurred during a continued fall in the citing of German theses as separate monographs.

\footnotetext{
Tahresverzeichnis, op. cit.
}

TABLE 3

Distribution of German University THeses Published as Serial Articles in Six Selected Years, 1895-1921*

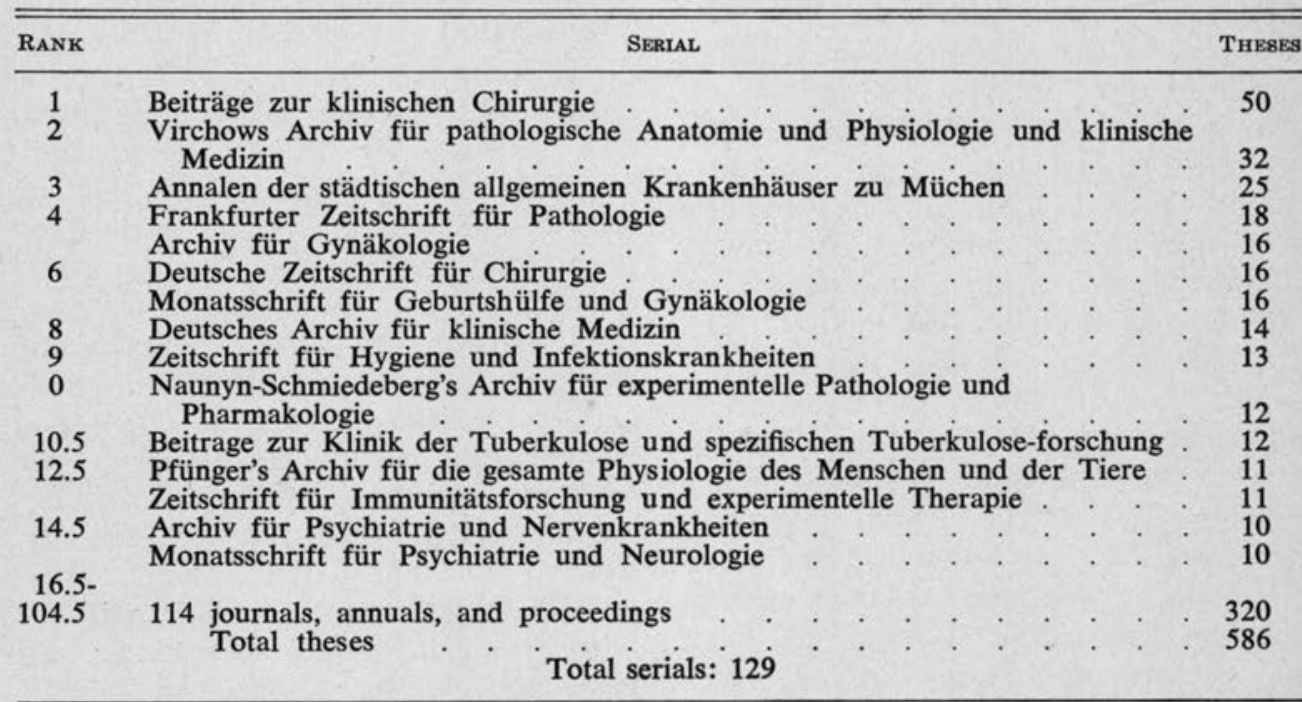

* Source: Jahresverzeichnis der deutschen Hochschulschriften, academic years 1895-96, 1900-01, 1905-06, 191011 , and calendar years 1916, 1921. 
Further evidence which seems to support this belief is revealed when the ranks of German universities by number of theses cited (from Table 2) is compared with their ranks established from the proportions of their theses published as serial articles (from the Jahresverzeichnis sample). With the exception of Köln, which did not grant medical degrees until after World War I, there appears to be an inverse correlation of varying degree in their standings. Frankfurt, ranked twentieth of twenty-eight German universities in distribution of theses cited, was the first of twenty-four in the proportion of its theses published in serials. Heidelberg, seventeenth in theses cited, was second in theses published. In the same order Berlin ranked first and sixteenth.

Distribution in serial article form offers to the dissertation of merit and substance greater circulation and currency than it might secure as a separate monograph. This publication device, for a long period peculiar to German theses, has likely had considerable effect on the citation use of the separate German monographic dissertation. The following additional factors have probably contributed, in varying degrees, to the universal disuse of the separately published thesis by the medical writer: shifting emphases in medical education; the growth in the variety and number of medical journals; the stress upon currency in the communication of medical information; and the team approach to medical research, with its possible minimizing of the thesis contribution of the individual.

Table 3 offers a ranked list of serial publications containing German university dissertations in article form, derived from a complete count of theses in Jahresverzeichnis der deutschen Hochschulschriften, for every fifth year from 189596 to $1921 .^{8}$ The wide variety of medical subjects and specialties, and the large number of serials represented, are noteworthy.

Ibid.

\section{CONCLUSIONS}

The greatest citation use of the medical thesis as a separate monograph was made from about 1880 to 1910 . Theses cited in this period of heavy use have become a part of the historical record of medicine, and appear to have no worth now other than a clear historical value.

The thesis has suffered increasing disuse in the scientific information-communication explosion of this century, and its rate of disuse is higher generally than that of books, reports, etc. Unless the trend noted since $1911-20$ is broken or reversed, the thesis as a source for medical citation seems doomed to insignificance. The dissertation of today, except perhaps in the Scandinavian countries and France, appears to be little more than an educational or research exercise, offering almost nothing to medical progress.

Available data demonstrate only a token citation use of the thesis now. Although local, state and national considerations may demand the general collecting of theses as depository material, their selective collection for actual or expected historical value would appear to offer the fairest exchange for processing expended and shelf space used.

The authors are grateful to Ursula E. Price, reference librarian, Yale medical library, for assistance in procuring needed materials; to Dr. Bruno Z. Kisch, curator, Edward C. Streeter, collection of weights and measures, Yale medical library, for information on German medical education; to Dr. Colin White, associate professor of public health (biometry), Yale University school of medicine, for statistical counsel; to Dr. André Hahn, head, library of the faculty of medicine, University of Paris, for information on Paris theses; to Lee Ash, editor and research analyst, selective book retirement program, Yale University library, for many useful suggestions; and particularly to the Council on Library Resources for the grant which made this study and report possible. 